УДК 330.522.4:351.711(477)

DOI: https://doi.org/10.26642/jen-2021-3(97)-41-46

\author{
І.В. Голінка \\ Ю.М. Білоконь \\ УкрНДІ «Ресурс», м. Київ
}

\title{
Створення запасів матеріальних цінностей державного матеріального резерву у сучасних умовах
}

\author{
(Представлено: д.е.н., проф. Новищький Андрій Миколайович)
}

\begin{abstract}
У статті здійснено системний аналіз та узагальнення проблем, які під час створення, накопичення та зберігання запасів матеріальних цінностей для забезпечення виконання законодавчо встановлених призначень державного матеріального резерву. Досліджено причинно-наслідкові зв'язки, щзо обумовлюють критичний стан системи державного матеріального резерву України. За результатами проведеного дослідження пропонується 3 метою подолання негативної тенденції зниження обсягів запасів у державному матеріальному резерві використати комплексний підхід, який забезпечить концентрацію зусиль $і$ фінансових ресурсів для накопичення та утримання оптимальних за номенклатурою та обсягами матеріальних иінностей. Комплексний підхід передбачає розроблення пропозицій для внесення змін до законодавства щьоо перегляду призначення державного матеріального резерву виходячи з сучасних умов, та низку заходів з покращення діяльності щуодо створення запасів матеріальних иінностей.
\end{abstract}

Ключові слова: державний матеріальний резерв; запаси; матеріальні иінності; номенклатура матеріальних ијнностей; обсяги накопичення; фінансові резерви.

Постановка проблеми. Відомо, що країни створюють стратегічні резерви матеріальних цінностей як інструмент страхування від можливих ризиків ресурсних обмежень різного характеру - воєнних, техногенних, ринкових тощо. Державні матеріальні резерви підтримуються у більшості розвинутих економік світу. Значні обсяги резервів створені та утримуються в США, країнах Свросоюзу, Китаї. При цьому, історія свідчить, що значні обсяги резервів можуть собі дозволити лише сильні, економічно спроможні держави.

Підтримання в належному стані запасів державного матеріального резерву є важливим чинником у сфері забезпечення національної та економічної безпеки, який спрямований на поступове зміцнення економічної стійкості та посилення невразливості національної економіки до зовнішніх і внутрішніх загроз.

Водночас за даними аудиторського звіту щодо результатів державного аудиту виконання бюджетних програм у Державному агентстві резерву України за період з 01.01.2013 до 31.12.2016, що складений Державною аудиторською службою України, запаси державного матеріального резерву знаходяться у критичному та найгіршому стані з моменту створення цього резерву ще за радянських часів. Відпуск матеріальних цінностей постійно перевищує кількість закладеного [1].

Подолання цієї негативної тенденції можливе шляхом визначення причин, які сприяють зменшенню запасів ресурсів у державному матеріальному резерві, та розробки рекомендацій щодо заходів для подолання кризового стану створення запасів матеріальних цінностей.

Аналіз останніх досліджень та публікації, на які спираються автори. В сучасній економічній літературі наявні дослідження окремих питань щодо функціонування державного матеріального резерву такими науковцями та практиками, як Коваленко С.О. [2], Мельник В.І., Погріщук Б.В. [3], Тарасюк О.Б. [4], Ващенко В.В. [5]. Нами, у попередніх працях було розглянуто питання підвищення ефективності управління системою державного матеріального резерву України [6] та питання удосконалення процедур реалізації матеріальних цінностей [7].

Водночас, питання щодо підходів до створення запасів та формування номенклатури матеріальних цінностей державного матеріального резерву в сучасних умовах опрацьовані недостатньо.

Метою статті $\epsilon$ аналіз та встановлення причин критичного стану діяльності системи державного матеріального резерву для пошуку підходів до формування запасів матеріальних цінностей у сучасних умовах з метою виконання законодавчо встановленого призначення державного матеріального резерву України. Слід зазначити, що питання запасів мобілізаційного резерву в даному дослідженні не розглядаються.

Викладення основного матеріалу. Доступні впродовж останніх років дані, а також публікації у засобах масової інформації лише підтверджують складність ситуації. Фактично за всі 30 років існування

(C) І.В. Голінка, Ю.М. Білоконь, 2021 
державного матеріального резерву в Україні його запаси мають сталу тенденцію до зменшення і за кількістю позицій в номенклатурі, а також за обсягами в цілому.

Так за результатами перевірки використання цінностей державного матеріального резерву України у 2000 році вказувалося, що за період, який перевірявся, відпуск матеріальних цінностей з державного резерву постійно перевищує кількість закладеного. Вивчення питання використання матеріальних цінностей держрезерву підтвердило, що нині їх запаси знаходяться в найгіршому стані з моменту створення Держкомрезерву. При цьому слід підкреслити, що Уряд не дотримується чинних актів щодо використання матеріальних цінностей держрезерву, а проводить політику інтенсивного їх витрачання i фактично поклав на Держкомрезерв функції оператора 3 постачання матеріально-технічних ресурсів. Підтвердженням цього є той факт, що в 1997-1998 роках за рахунок паливно-мастильних матеріалів державного резерву проводилися польові роботи сільськогосподарськими товаровиробниками. А в 1999 році Кабінет Міністрів України постановою від 10.12.98 № 1953 вже повністю поклав на Держкомрезерв функцію забезпечення нафтопродуктами сільгосптоваровиробників [8].

Інтенсивне використання запасів державного резерву впродовж 1997-1999 років шляхом їх позичання окремим галузям народного господарства призвело до збільшення дебіторської заборгованості Держкомрезерву, яка лише за 1998 рік зросла в 1,6 раза. Станом на 01.01.99 вона складала майже 3,2 млрд грн, 3 яких на суму 1854,6 млн грн рішеннями Уряду було продовжено термін повернення на 2001-2003 роки, на 01.01.2000 3,1 млрд грн, а на 01.07.2000 - 3 млрд грн.

Отже, істотне зменшення обсягів матеріальних цінностей в державному матеріальному резерві внаслідок відпуску значної кількості запасів на виконання урядових рішень щодо надання державної підтримки підприємствам електроенергетики, хімічної промисловості, сільськогосптоваровиробникам, цукровим заводам тощо, а також критичним було невиконання останніми договірних зобов'язань в частині повернення запозичених ресурсів.

Таким чином, вирішення поточних задач надання державної підтримки галузям народного господарства 3 метою стабілізації економіки шляхом відпуску матеріальних цінностей з державного матеріального резерву без організації відповідного поповнення його запасів, послабило спроможність Держрезерву забезпечувати виконання законодавчо встановлених призначень і фактично унеможливило його участь у заходах, спрямованих на стабілізацію економіки у подальшому.

Відповідно до Аналітичного звіту за результатами ревізії у Державному комітеті України 3 державного матеріального резерву встановлено наступне. Закони про Державний бюджет України на 2006-2009 роки передбачали фінансування системи державного резерву виключно за кошти від реалізації матеріальних цінностей державного резерву, а чинний Порядок № 1078 передбачав можливість їх реалізації за цінами, нижчими за ринкові та облікові. Зокрема Порядком № 1078 визначено, що ціна придбання не може бути меншою від гарантійного внеску, що становить 25 \% стартової (ринкової) вартості [9].

Загальновідомо, що накопичення та зберігання запасів ресурсів вимагає значних фінансових асигнувань. Водночас фінансування накопичення, поповнення, а також, що вкрай важливо, навіть обслуговування матеріальних цінностей у державному матеріальному резерві здійснюється за рахунок коштів спеціального фонду державного бюджету, а саме за рахунок надходжень від реалізації цих запасів. Зрозуміло, що без залучення додаткового фінансування обсяги ресурсів в державному матеріальному резерві будуть неминуче знижуватися. На жаль, дана ситуація триває і дотепер.

Окрім того, проведений фахівцями Держкомрезерву аналіз стану державного резерву на 01.01.2009 проти 01.01.1992 підтвердив зменшення кількості найменувань державних запасів, наприклад, номенклатура промислових товарів, сировини та матеріалів зменшено - 316 до 4 найменувань, металопродукції - 346 до 5, продовольчих товарів - 321 до 8. Упродовж 2007-2009 років номенклатуру запасів держрезерву скоротилася 377 до 38 найменувань, або в 2 рази. У травні 2009 року скорочено норми незнижуваних запасів за основними видами продовольства (цукор - у 10 разів, олія - втричі, зерно удвічі, м'ясо - на 40 \%), авіапалива (у 8 разів), бензину (на 60 \%), дизельного палива (наполовину); виведено 3 номенклатури 4 види промислової продукції [10]. Не потребує доведення той факт, що формування занадто великих запасів є економічно обтяжливим, а малих запасів - зробить неможливим виконання поставлених завдань, тож пошук науково обгрунтованих рішень щодо оптимального запасу $\epsilon$ актуальним завданням для держави в сучасних умовах економічної нестабільності та пандемії.

Також, на стан запасів державного матеріального резерву негативно впливають численні випадки незабезпечення їх збереження підприємствами відповідальними зберігачами та неефективне управління запасами матеріальних цінностей, особливо продовольчої групи товарів, внаслідок чого спливає їх термін придатності, що не тільки унеможливлює реалізацію цієї продукції, але й вимагає додаткового фінансування для іiї утилізації.

Все перераховане вище вказує на необхідність переосмислення та корегування норм, якими визначені призначення державного матеріального резерву. Так статтею 3 Закону України «Про державний матеріальний резерв» [11] визначено, що державний матеріальний резерв призначається для: 
1) забезпечення потреб України в особливий період; 2) надання державної підтримки окремим галузям народного господарства, підприємствам, установам і організаціям з метою стабілізації економіки у разі тимчасових порушень термінів постачання важливих видів сировини і паливно-енергетичних ресурсів, продовольства, виникнення диспропорції між попитом і пропонуванням на внутрішньому ринку та участь у виконанні міждержавних договорів; 3) подання гуманітарної допомоги; 4) забезпечення першочергових робіт під час ліквідації наслідків надзвичайних ситуацій.

При цьому забезпечення виконання державним матеріальним резервом у повному обсязі законодавчо встановлених призначень вимагає накопичення та зберігання значних обсягів матеріальних цінностей, досить різної та значної за розмірами номенклатури, що в сучасних умовах не відповідає економічній спроможності країни.

В цілому, роль держави і ступінь ї втручання в економічне життя доцільно розглядати за показниками результативності їі діяльності. У липні 2009 року за рішеннями Уряду започатковано заходи щодо стабілізації ситуації на внутрішньому ринку цукру. Було передбачено відпустити 3 державного резерву 10 тис. т цукру визначеним Мінекономіки підприємствам роздрібної торгівлі для реалізації його населенню та забезпечити поповнення запасів цукром, виробленим із цукрових буряків урожаю 2009 року. Надалі було передбачено Держкомрезерву відпустити 3 державних запасів ще 28 тис. т цукру підприємствам його системи для подальшої реалізації населенню безпосередньо на продовольчих ринках 3 мінімальною торговельною надбавкою. I хоча відпуск цукру було здійснено практично у повному обсязі (37,9 тис. т за ціною 3500 грн/т на суму 132,6 млн грн) та аналогічну за обсягами інтервенцію цукру у цей період здійснив Аграрний фонд Мінагрополітики, це несуттєво позначилося на стабілізації цін: упродовж липня-грудня 2009 року роздрібні ціни на цукор зросли з 3,5 до 7,6 грн/кг.

Отже, концентрація ресурсів на виконанні стабілізаційних заходів на ринку продовольства, на придбання яких $з$ державного бюджету витрачено загалом 1,5 млрд грн. (іноземне м'ясо - 1364 млн грн, цукор - 132,6 млн грн), через мізерну питому вагу реалізованої на ринку продукції в загальному обсязі споживання суттєво не вплинула на зниження цін на м'ясо та цукор [10].

Аналіз результатів діяльності Держрезерву свідчить, що фактично більше ніж 10 останніх років стан запасів державного матеріального резерву не дозволяє їх використання для надання суттєвої державної підтримки окремим галузям народного господарства, підприємствам, установам і організаціям 3 метою стабілізації економіки. Таким чином, складний економічний стан та невдалий досвід практичного застосування такого інструменту в нашій державі, що наведено вище, свідчить про доцільність зміни способів надання державної підтримки для стабілізації економіки. Зокрема, в умовах обмежених можливостей державного бюджету для надання державної підтримки галузям, підприємствам та установам народного господарства більш ефективнішим та оптимальнішим буде застосування інших напрямів державної політики, а саме законодавчого регулювання податкових та інших преференцій, прямого або непрямого субсидування з державного бюджету.

Наприклад, для надання державної підтримки може бути застосоване не тільки матеріальне резервування, яке притаманне Україні та іншим країнам пострадянського простору, але й запровадження фінансових резервів (розпорядження якими буде здійснюватися не обов'язково Держрезервом), що являють собою особливу групу фондів грошових коштів, в яких нагромаджуються кошти, які на деякий час вилучаються з обороту з метою використання у випадках збоїв у процесі суспільного виробництва та необхідності надання державної підтримки [4].

Такий підхід сприятиме концентрації фінансових ресурсів Держрезерву для створення запасів матеріальних цінностей, які спроможні задовольнити забезпечення потреб України в особливий період та першочергових робіт під час ліквідації наслідків надзвичайних ситуацій; а також подання гуманітарної допомоги та участі у виконанні міждержавних договорів. Це надасть можливість корегувати номенклатуру та обсяг запасів матеріальних цінностей Держрезерву, оптимізувати їх відповідно до зазначених вище призначень державного матеріального резерву.

Наприклад, припинення практики зберігання в державному матеріальному резерві зерна. Створення та підтримання таких запасів у належному стані вимагають досить значних бюджетних асигнувань. Водночас, стала тенденція істотного зростання врожаю зернових, яка спостерігається впродовж останніх років в нашій державі, існуюча практика інших країн стосовно переходу до зберігання в державному резерві консервованої продукції замість зерна, активна позиція на ринку іншого державного оператора, а саме - Аграрного фонду [6] - все це свідчить про користь та своєчасність такого рішення.

Також у зв'язку із неминучістю виконання Україною зобов'язань стосовно імплементації вимог директиви 2009/СС щодо створення та утримання стабілізаційних запасів нафти і нафтопродуктів [12], на часі питання корегування номенклатури та обсягів накопичення нафтопродуктів у державному матеріальному резерві. Тобто, формування державних стабілізаційних запасів бензину та дизельного палива, які здійснюватимуться на виконання згаданої директиви, сприятиме здійсненню перегляду обсягів зберігання цих нафтопродуктів в державному матеріальному резерві у бік зменшення, наприклад 
на рівнях незнижуваного запасу, при цьому збільшується можливість здійснення накопичення та зберігання запасів авіапалива та олив.

Важливим аспектом оптимізації обсягів запасів ресурсів та кількості позицій номенклатури в державному матеріальному резерві $є$ уникнення практики створення однакових запасів державних матеріальних цінностей різними відомствами [5]. Напевно настав час, коли Мінекономіки як головний орган у системі центральних органів виконавчої влади, що забезпечує формування та реалізує державну політику економічного розвитку, спільно з іншими центральними органами виконавчої влади і, у першу чергу Мінфіном, повинно забезпечити здійснення аналізу запасів страхових ресурсів, на які витрачаються фінансові асигнування для виконання бюджетних програм різними органами виконавчої влади. Здійснення комплексного аналізу призначень запасів ресурсів для різних відомств спільно із станом цих запасів сприятиме уникненню розпорошень досить обмежених бюджетних асигнувань між цими відомствами при формуванні таких запасів і покращить ефективність використання цих ресурсів.

На нашу думку, номенклатура матеріальних цінностей державного матеріального резерву повинна передбачати виключно запаси матеріально-технічних ресурсів для виконання першочергових робіт під час ліквідації наслідків надзвичайних ситуацій і ніяким чином не охоплювати ресурси, що необхідні для запобігання таким ситуаціям.

Матеріальні цінності в номенклатурі державного матеріального резерву повинні мати універсальний характер і бути максимально спрямованими на забезпечення потреб органів виконавчої влади, що здійснюють закупівлю аналогічної продукції за бюджетні кошти. Такий підхід сприятиме наявності сталого попиту для матеріальних цінностей державного резерву з боку інших бюджетних замовників, дозволить запобігати утворенню продукції із простроченими термінами зберігання, забезпечить ефективне використання фінансових ресурсів.

Крім цього, окремого розгляду вимагає зарубіжний досвід зберігання державних матеріальних резервів, зокрема в сусідній Польщі, де широко застосовується приватно-державне партнерство [13]. Важливим питанням $є$ забезпечення збереження матеріальних цінностей державного матеріального резерву відповідальними зберігачами. Запровадження конкурсного відбору відповідальних зберігачів, посилення відповідальності за збереження матеріальних цінностей разом із здійсненням своєчасних розрахунків за збереження запасів, припинення кадрової чехарди 3 керівниками підприємств та організацій, що входять до єдиної системи державного матеріального резерву, - це неповний перелік заходів, які сприятимуть наведенню елементарного порядку із забезпеченням збереження запасів ресурсів. Так запровадження зберігання матеріальних цінностей державного матеріального резерву із короткими строками придатності (наприклад, бутильованої питної води, борошна тощо) у виробників цієї продукції автоматично вирішує питання її освіження без необхідності здійснення довготривалих і не завжди результативних процедур реалізації та закупівлі.

Висновки 3 даного дослідження і перспективи подальших розвідок у цьому напрямі. Загальний стан запасів матеріальних цінностей державного матеріального резерву можна охарактеризувати як проблемний, з відсутністю тенденцій до покращення. У разі не вжиття невідкладних заходів це призведе до незворотніх процесів.

На наш погляд, в умовах обмежених можливостей державного бюджету подолати негативну тенденцію суцільного зниження обсягів запасів у державному матеріальному резерві можливо шляхом запровадження концентрації зусиль і фінансових ресурсів для накопичення та утримання оптимальних за номенклатурою та обсягами запасів матеріальних цінностей. Рекомендуємо використати комплексний підхід, який варто реалізувати через низку заходів:

- розробити пропозиції для внесення змін до законодавства щодо перегляду призначення державного матеріального резерву виходячи з сучасних реалій та фінансової спроможності держави;

- оптимізувати номенклатуру та обсяги накопичення матеріальних цінностей в державному матеріальному резерві із врахуванням його призначень, а також потреб органів виконавчої влади, що здійснюють закупівлю аналогічної продукції за бюджетні кошти;

- $\quad$ запровадити поряд з матеріальним резервуванням наявність фінансових резервів;

- уникати практики створення державних запасів однакових матеріальних цінностей різними відомствами;

- $\quad$ запровадити відбір відповідальних зберігачів матеріальних цінностей державного матеріального резерву на конкурсних засадах, а також залучення до відповідального зберігання виробників продукції, особливо для запасів ресурсів із короткими строками придатності.

Настав час прийняття виважених і обгрунтованих управлінських рішень, спрямованих на організацію формування та підтримання в належному стані резерву матеріальних цінностей з метою забезпечення збереження сутності та призначення державного матеріального резерву як невід'ємного компонента забезпечення стратегічних потреб і національної безпеки держави. 
Список використаної літератури:

1. Аудиторський звіт за результатами державного аудиту виконання бюджетних програм у Державному агентстві резерву України за період з 01.01.2013 до 31.12.2016 / Державна Аудиторська служба України. - К., 2017. - 79 с. [Електронний ресурс]. - Режим доступу : http://dkrs.kmu.gov.ua/kru/doccatalog/document?id=131445.

2. Коваленко С.О. Державний матеріальний резерв України: проблеми та перспективи функціонування / С.О. Коваленко // Вісник ХНАУ. Серія : Економічні науки. - 2016. - № 1. - С. 100-108 [Електронний pecypc]. - Режим доступу : http://nbuv.gov.ua/UJRN/Vkhnau_ekon_2016_1_13.

3. Мельник B.I. Організаційно-економічні засади перспективного розвитку державного резерву України / B.I. Мельник, Б.В. Погрішук // Науковий вісник Ужгородського університету. Серія : Економіка. - 2020. № 1 (55). - С. 36-40 [Електронний ресурс]. - Режим доступу : http://visnyk-ekon.uzhnu.edu.ua/article/view/213345.

4. Тарасюк О.Б. Сутність державного матеріального резервування / О.Б. Тарасюк, О.О. Кас'янова // Актуальні проблеми економіки. - 2012 - № 6. - С. 91-95 [Електронний ресурс]. - Режим доступу : http://nbuv.gov.ua/UJRN/ape_2012_6_12.

5. Ващенко B.B. Сутність формування та розвитку державного агентства резерву України / В.B. Ващенко // Економіка. Менеджмент. Бізнес. - 2015. - № 1. - С. 126-131 [Електронний ресурс]. - Режим доступу : http://nbuv.gov.ua/UJRN/ecmebi_2015_1_20.

6. Голінка I.B. Шляхи підвищення ефективності управління системою державного матеріального резерву України / І.В. Голінка, Ю.М. Білоконь, Л.Л. Кісіль // Вісник Національного університету цивільного захисту України. Серія : Державне управління. - Х. : Вид-во НУЦЗУ, 2020. - Вип. 2 (13). - С. 273-288.

7. Голінка I.B. Удосконалення процедур реалізації матеріальних цінностей державного матеріального резерву // І.В. Голінка, Ю.П. Шамрай, Ю.М. Білоконь // Економіка, управління та адміністрування. - 2020. № 4 (94) [Електронний ресурс]. - Режим доступу : https://doi.org/10.26642/ema-2020-4(94)-106-109.

8. Про результати перевірки використання цінностей державного матеріального резерву України / За матеріалами Колегії Рахункової палати від 04.09.2000 року ; Відпов. за випуск департамент контролю видатків на АПК та виробничу інфраструктуру. - Київ : Рахункова палата України, 2000. - Вип. 23 [Електронний ресурс] - Режим доступу : rada.gov.ua/control/main/uk/publish/article/168602;jsessionid=FD7EE3EBA616FA3DF1A5E8668604E81C.

9. Про результати ревізії у Державному комітеті України з державного матеріального резерву / Аналітичні звіти за січень-жовтень 2009 [Електронний ресурс]. - Режим доступу : http://dkrs.kmu.gov.ua/kru/uk/publish/article/63488;jsessionid=683FB7EC88E2BB76659846910DCC21E4.app1.

10. Про ефективність використання бюджетних коштів на обслуговування та накопичення матеріальних цінностей державного матеріального резерву. - 23 травня 2011 [Електронний ресурс]. - Режим доступу : http://dkrs.kmu.gov.ua/kru/uk/publish/article/74280;jsessionid=98793A091DEE31278A6ACFA4C1C95CE1.app1 .

11. Про державний матеріальний резерв : Закон України від 24 січня 1997 року № 51/97-ВР [Електронний pecypc]. - Режим доступу : https://zakon.rada.gov.ua/laws/show/51/97-\%D0\%B2\%D1\%80\#Text.

12. Про імплементацію Угоди про асоціацію між Україною, з однієї сторони, та Європейським Союзом, Свропейським Співтовариством 3 атомної енергії і їхніми державами-членами, 3 іншої сторони : Розпорядження Кабінету Міністрів України від 17.09.2014 № 847-р [Електронний ресурс]. - Режим доступу : https://zakon.rada.gov.ua/laws/show/847- 2014 -\%D1\%80.

13. Коваленко С.О. Державний матеріальний резерв України: проблеми та перспективи функціонування / С.О. Коваленко // Вісник ХНАУ. Серія : Економічні науки. - 2016. - № 1. - С. 100-108 [Електронний pecypc]. - Режим доступу : http://nbuv.gov.ua/UJRN/Vkhnau_ekon_2016_1_13.

\section{References:}

1. Derzhavna Audytors'ka sluzhba Ukrai'ny (2017), «Audytors'kyj zvit za rezul'tatamy derzhavnogo audytu vykonannja bjudzhetnyh program u Derzhavnomu agentstvi rezervu Ukrai'ny za period z 01.01.2013 do 31.12.2016, K.,.79 p., [Online], available at: http://dkrs.kmu.gov.ua/kru/doccatalog/document?id=131445

2. Kovalenko, S.O. (2016), «Derzhavnyj material'nyj rezerv Ukrai'ny: problemy ta perspektyvy funkcionuvannja», Visnyk HNAU, Serija Ekonomichni nauky, No. 1, pp. 100, [Online], available at: http://nbuv.gov.ua/UJRN/Vkhnau_ekon_2016_1_13

3. Mel'nyk, V.I. and Pogrishhuk, B.V. (2020) «Organizacijno-ekonomichni zasady perspektyvnogo rozvytku derzhavnogo rezervu Ukrai'ny», Naukovyj visnyk Uzhgorods'kogo universytetu, Serija Ekonomika, No. 1 (55), pp. 36-40, [Online], available at: http://visnyk-ekon.uzhnu.edu.ua/article/view/213345

4. Tarasjuk, O.B. and Kas'janova, O.O. (2012), «Sutnist' derzhavnogo material'nogo rezervuvannja», Aktual'ni problemy ekonomiky, No. 6, pp. 91-95, [Online], available at: http://nbuv.gov.ua/UJRN/ape_2012_6_12

5. Vashhenko, V.V (2015), «Sutnist' formuvannja ta rozvytku derzhavnogo agentstva rezervu Ukrai'ny», Ekonomika. Menedzhment. Biznes, No. 1, pp. 126-131, [Online], available at: http://nbuv.gov.ua/UJRN/ecmebi_2015_1_20

6. Golinka, I.V., Bilokon' Ju.M. and Kisil' L.L. (2020), «Shljahy pidvyshhennja efektyvnosti upravlinnja systemoju derzhavnogo material'nogo rezervu Ukrai'ny», Visnyk Nacional'nogo universytetu cyvil'nogo zahystu Ukrai'ny, Serija Derzhavne upravlinnja, Vol. 2 (13), pp. 273 -288.u

7. Golinka I.V., Shamraj, Ju.P. and Bilokon', Ju.M. (2020), «Udoskonalennja procedur realizacii' material'nyh cinnostej derzhavnogo material'nogo rezervu», Ekonomika, upravlinnja ta administruvannja, No. 4 (94), pp. 106-109.

8. Rahunkova palata Ukrai'ny (2000), «Pro rezul'taty perevirky vykorystannja cinnostej derzhavnogo material'nogo rezervu Ukrai'ny», Za materialamy Kolegii' Rahunkovoi' palaty vid 04.09.2000 roku, Vidpov. za vypusk 
departament kontrolju vydatkiv na APK ta vyrobnychu infrastrukturu, Vol. 23, [Online], available at: http://old.acrada.gov.ua/control/main/uk/publish/article/168602;jsessionid=FD7EE3EBA616FA3DF1A5E8668604E81C

9. «Pro rezul'taty revizii' u Derzhavnomu komiteti Ukrai'ny z derzhavnogo material'nogo rezervu» (2009), Analitychni zvity $\quad z a$ sichen'-zhovten', [Online], available at: http://dkrs.kmu.gov.ua/kru/uk/publish/article/63488;jsessionid=683FB7EC88E2BB76659846910DCC21E4.app1

10. «Pro efektyvnist' vykorystannja bjudzhetnyh koshtiv na obslugovuvannja ta nakopychennja material'nyh cinnostej derzhavnogo material'nogo rezervu» (2011), [Online], available at: http://dkrs.kmu.gov.ua/kru/uk/publish/article/74280;jsessionid=98793A091DEE31278A6ACFA4C1C95CE1.app1

11. VRU (1997), «Pro derzhavnyj material'nyj rezerv», Zakon Ukrai'ny, No. 51/97-VR, [Online], available at: https://zakon.rada.gov.ua/laws/show/51/97-\%D0\%B2\%D1\%80\#Text

12. Kabinet Ministriv Ukrai'ny (2014), «Pro implementaciju Ugody pro asociaciju mizh Ukrai'noju, z odnijei' storony, ta Jevropejs'kym Sojuzom, Jevropejs'kym Spivtovarystvom z atomnoi' energii' i i'hnimy derzhavamy-chlenamy, z inshoi' storony», Rozporjadzhennja vid 17 veresnya No.847-r., [Online], available at: https://zakon.rada.gov.ua/laws/show/847- 2014 -\%D1\%80

13. Kovalenko, S.O. (2016), «Derzhavnyj material'nyj rezerv Ukrai'ny: problemy ta perspektyvy funkcionuvannja», Visnyk HNAU, Serija Ekonomichni nauky, No. 1, pp. 100-108, [Online], available at: http://nbuv.gov.ua/UJRN/Vkhnau_ekon_2 016_1_13

Голінка Інна Василівна - заступник начальника відділу науково-технічної інформації, стандартизації та інформатизації Українського державного науково-дослідного інституту «Ресурс» Державного агентства резерву України.

https:// orcid.org/0000-0002-1271-1788.

Наукові інтереси:

- теорія, методологія та організація державного управління і моделі систем державного матеріального резерву у різних країнах світу й Україні;

- наукові підходи і шляхи підвищення ефективності та результативності діяльності системи державного матеріального резервування.

Білоконь Юрій Миколайович - в. о. старшого наукового співробітника відділу контролю запасів державного матеріального резерву лабораторії досліджень хіміко-біологічних Українського державного науково-дослідного інституту «Ресурс» Державного агентства резерву України, «Заслужений працівник промисловості України».

https:// orcid.org/0000-0001-5503-7247.

Наукові інтереси:

- наукові підходи та шляхи підвищення ефективності й результативності діяльності системи державного матеріального резервування.

Стаття надійшла до редакції 15.07.2021. 